\title{
日本の地域産業連関表作成の 現状と課題
}

\section{石川 良文}

我が国で初めて地域産業連関表が作成されてから半世紀以上が 経過し, 現在では比較的大きなブロック単位から市町村レベル まで数多くの地域産業連関表が整備されるようになった.この 状況は地域産業連関分析の発展と実際の政策分析二ーズに応え るために喜ばしい状況であると言える. しかし, 今後永続的に 地域産業連関表が作成され, 各方面で活用されるためには今一 度その作成の経緯と実態を明らかにし, 今後の産業連関表作成 の課題を検討する必要がある. 本稿では, 全国の都道府県, 政 令指定都市に対して行った実態調查を踏まえ, 地域産業連関表 の整備状況を概観すると共に今後の作成上の課題を検討する.

\section{1. はじめに}

我が国の地域産業連関表の歴史は長く，世界 的に見てもその発展は目覚ましい. 関西経済連 合会が 1957 年に 1951 年を対象年次とした近畿 地域産業連関表を発表して以来，1958 年には 愛知県が 1953 年愛知県産業連関表を公表する など都道府県での作成も進められた。北海道, 宮城県, 山形県, 大阪府, 兵庫県, 山口県, 熊 本県などでは同時期に地域産業連関表が公表さ れ, その後作成する都道府県は増加し 1990 年 を対象年次とする表から全ての都道府県で作成
されるようになった（渡部（2008））。また，日 本が誇る地域産業連関表に経済産業省による地 域産業連関表がある。この表には 1960 年以来 5 年ごとに全国を 9 地域に分割した地域内産業 連関表と,さらに地域内表を連結した地域間産 業連関表があり，これらの表の作成においては 商品流通調查等を活用し地域間交易の把握に努 めている。本格的なサーベイ手法による全国を 対象とした地域間表であり，半世紀にもわたる 長い期間作成されてきたことから非常に価值の ある地域表と言える。また, 都道府県や日本を いくつかの大ブロックに分割した地域産業連関 表の他にも比較的小さな地域を対象とした産業 
連関表の作成も活発に行われている。特に近年 では地域経済の低迷や地方創生の機運などもあ り，小地域を対象とした産業連関表も数多く作 成されている。

このように我が国の地域産業連関表作成事情 は，世界の中でも極めて充実した整備状況にあ ると言えるが, 今後も日本の地域産業連関表が 着実に作成され，それを利用した各種分析も活 発に行われることが期待される。そこで, 本稿 ではこれまでの我が国における地域産業連関表 の作成経緯を概観すると共に, 主に都道府県と 政令指定都市に着目し, 実態調査を通じてその 整備状況と作成手法等から現在の地域産業連関 表作成の抱える課題と展望を考察する。

\section{2. 地域産業連関表の作成経緯}

Leontief（1936）が 1936 年に初めてアメリ カの 1919 年産業連関表を提示して以来, 世界 各国で国を対象とした産業連関表が作成されて いる。地域を対象とした産業連関表は, 1951 年に Isard（1951）によってその概念が示され ると, 各国で地域産業連関表が作成され, 地域 を対象とした各種分析も可能になった。初期の 産業連関表は, Moore \& Petersen（1955）に よるユ夕地域を対象にしたものや, Hirsh （1959）のセントルイス地域を対象とし, 直接 的に各産業部門間の相互取引額を調查し作成さ れた産業連関表などがあり，この頃から地域分 析のための産業連関表の利用が進められた。ま た, Chenery（1956）がイタリアの北部と南部 を分割した地域間産業連関表を作成し，それを 用いて北部と南部の地域間格差を分析し,

Moses（1955）もまた同時期にアメリカを東 部, 西部, 中西部の 3 つの地域に分割した地域 間表を作成している。そのほか米国ではワシン トン, カンザス, ウェストバージニア, テキサ ス，コロラド，ネブラスカなどアメリカの多く の州で地域産業連関表が作成されるようにな り，中でもサーベイ手法による代表的な地域表 であるワシントン産業連関表は, 1963 年から 5
年から 10 年ごとに作成されている。一時期ノ ンサーベイ手法を用いられた表もあったが，最 新の 2007 年表では，6,010 事業所を対象とし てアンケート調査が実施され 2,531 事業所 (42.1\%) から回答を得ている（Beyers and Lin (2015)).

近年では, 地域産業連関表の作成はより活発 になっており，ここでは網羅的に世界の地域産 業連関表の整備状況を紹介することはできない が，例えば中国においては，2002 年 30 省市自 治区産業連関表，2007 年 30 省市自治区産業連 関表が公開されている(岡本 (2013))。また, 地域間表も市村 (2004), アジア経済研究所 （2003）などがそれぞれ作成している.

我が国では，日本一国を対象とした全国産業 連関表は 1951 年を対象年次として作成された 産業連関表が最初であり, その後 1955 年から 5 年ごとに産業連関表が作成されてきた。しか し 2015 年 6 月に公表された産業連関表は, 基 礎資料となる「経済センサス - 活動調査」が 2011 年を対象に実施されたことを受け，2011 年を対象年次としている.

既述したように地域を対象とした最初の試み は, 関西経済連合会による「近畿・その他地域 2 地域間産業連関表」であった。これは全国の 1951 年表をべースとして「近畿」「その他」地 域に分割した非競争移入型の地域間産業連関表 である。その後, 経済産業省 (旧通商産業省) が国内を 9 地域に分割した地域間産業連関表を 作成したのは 1960 年表からであり, 以後半世 紀にわたりその整備がされてきた1)。また，都 道府県では, 愛知県が 1953 年表を 1958 年に発 表したのをはじめ, 北海道, 宮城県, 山形県, 大阪府, 兵庫県, 山口県, 熊本県などでは同時 期に地域産業連関表が公表され，その後作成す る都道府県は増加し 1990 年を対象年次とする 表から全ての都道府県で作成されるようになっ た。

その他にも様々な地域産業連関表が作成され ている。例えば, 経済産業省の地域区分とは異 なる圈域を対象とした産業連関表として, 北陸 
地域産業連関表 (吹谷 (1994)), 東京圈産業連 関表（丸山（1992））などが作成された。さら に，都道府県内をいくつかの地域に分割した小 地域レベルの産業連関表は, 例えば三重県, 愛 媛県，北海道，兵庫県などで作成されている。 愛媛県はその先駆的な県であり，県内を $6 つ の$ 地域に分割したそれぞれの地域内産業連関表と 地域間産業連関表が 1978 年から 1998 年まで 5 年ごとに作成された (坪内 (1991))。また，三 重県の地域間産業連関表は，県下を 5 地域に分 割した 1985 年対象の地域間表が山田（1995） によって作成され，その後三重県が 1995 年, 2000 年表を作成している。北海道では, 北海 道開発局が 1985 年北海道産業連関表を基に 24 部門ベースで道央, 道南, 道北, 道東の 4 地域 別に分割したものが最初であり（高畑（1992）, 現在は 2005 年対象の 6 地域間産業連関表が入 手可能である。最近では，例えば兵庫県におい て兵庫県と神戸大学で構成する地域経済構造分 析研究会が兵庫県を 7 地域に区分した 2010 年 兵庫県内 7 地域産業連関表を作成している（芦 谷・後藤 $(2015))$.

市町村を対象とした産業連関表は，政令指定 都市を中心に整備されており，作成している自 治体は，札幌市，さいたま市，千葉市，横浜 市，川崎市，相模原市，大阪市，神戸市，広島 市，北九州市，福岡市である。なかでも神戸 市，横浜市，北九州市などは早い時期から作成 されており，神戸市は1955 年を対象とした産 業連関表から作成している。現在は作成されて いないが，名古屋市は比較的早期に産業連関表 の作成を手がけ，1969 年に 1965 年産業連関表 を作成している。その後は作成が行われていな かったが，朝日（2004）によって1995 年を対 象とした産業連関表が作成されている。市町村 レベルの産業連関表は近年盛んに作成されてい るため, 全てを網羅的に紹介することはできな いが，政令指定都市以外の市町村では，旭川市 が 1980 年表（亀畑・小野寺 (1991)）から 2000 年表（旭川市（2006））まで, 釧路市は 1970 年表から 2005 年表（釧路市（2015））ま
で作成されている.

近年，研究者レベルでも小地域産業連関表の 作成手法が議論されている。この議論の視点の 一つは，いかに既存の統計資料を用いながら効 率的かつ低コストで精度の高い産業連関表を作 成するかという点にあり，石川・小池・上田 （2001）では，小地域を対象とした産業連関表 の作成手法として Non-Survey 手法を検討し, 実際に岐阜市を対象とした産業連関表を作成し ている，また，本田・中澤（2000）では，舞鶴 市の産業連関表を作成している。石川ら，本田 らの採用した手法は結果的に類似した手法とな っているが，石川らは，地域間交易にS L Q 採用しており，輸移出・輸移入の分離がなされ ているのに対し, 本田らは輸移出・輸移入の分 離は行っていない。この点に関して中澤 （2002）は，工業部門の輸移出の実態調査を実 施し, 実態調查に基づく地域間交易の把握の可 能性を論じている。さらに，朝日（2004）は, 名古屋市を対象にした産業連関表を 93 部門と いう比較的細かい産業部門分類で作成してい る。この研究でも地域間交易の推計を石川と同 様にS L Q を用いている。この他日吉・河上・ 土井（2004）によるつくば市を対象とした産業 連関表，今西（2004）による深川市を対象とし た産業連関表，長谷川・安高（2009）による福 知山市の作成事例などがある。また，近年地方 創生が謳われるようになると，地域の産業連関 表の作成はより活発になっている。例えば岡山 県美作市では，イベント・観光事業の効果を分 析するために美作市産業連関表が作成されてい る(今井泉 (2015)).

さらに最近では，全国都道府県間の産業連関 表や大きな地域ブロックを都道府県単位で分割 した地域間産業連関表，国際産業連関表と日本 の地域間産業連関表を連結した国際地域間産業 連関表など様々な地域産業連関表が作成される ようになっている。例えば，全国 47 都道府県 間産業連関表の作成は，宮城・石川ら（2003） 以降各所で行われており，電力中央研究所 (2008)，萩原（2011）などでも作成されてい 


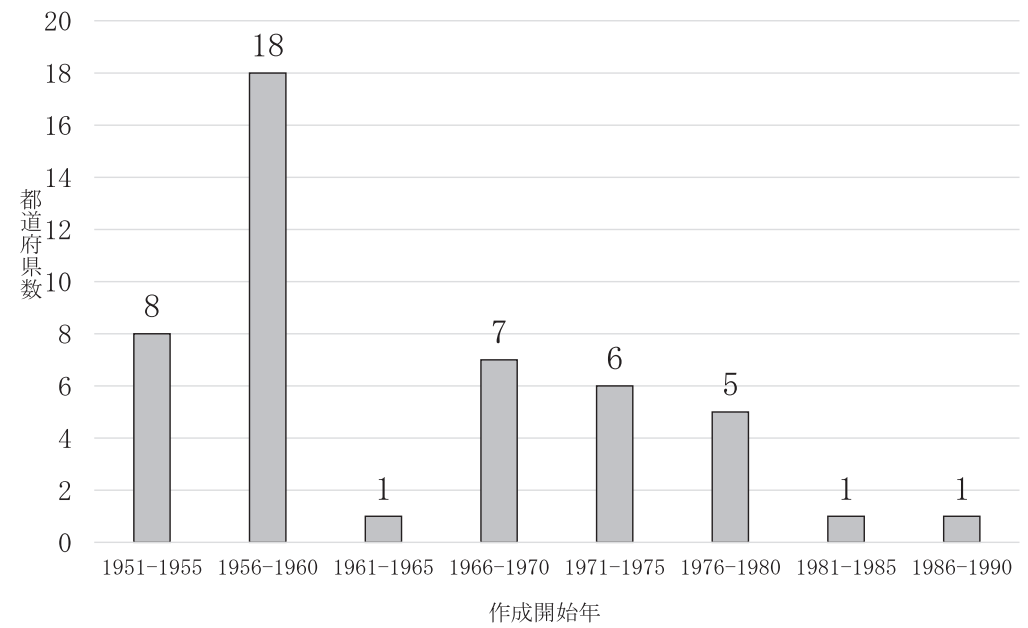

る。また，東北，中部，関西など広域のブロッ ク単位でも都道府県間産業連関表が東北活性化 研究センター (2011), 中部産業・地域活性化 センター (2011), 関西社会経済研究所 (2008) などで作成されている。そのほか国際産業連関 表と日本の地域産業連関表を連結した国際地域 間産業連関表としては，石川（2008）による九 州地域と中国, 韓国を連結したアジア国際日本 地域間産業連関表，アジア経済研究所 (2007) による日中地域間産業連関表などがある。

\section{3. 都道府県表と政令指定都市表 の実態}

\section{3-1 調查の概要}

我が国の都道府県及び政令市における地域産 業連関表の作成状況とその課題を明らかにする ため，全国 47 都道府県及び政令指定都市 20 市 に対してアンケート調査を実施した ${ }^{2)}$ 。調査に あたっては事前に地域産業連関表の作成状況を 各ホームページから把握し, その確認を担当部 局に行って頂いた。また，(1)作成状況，(2)作成 体制，(3)特別調查の実施，(4) 2011 年表の公表 と今後の作成，(5)分析ッールについて質問し た。調查の結果，46 都道府県，17 政令市から 回答を得た。以下に述べる調査結果は，これら
の回答のあった自治体の状況である。

\section{3-2 産業連関表作成状況}

\section{（1） 産業連関表作成開始年次}

我が国の都道府県では，愛知県における 1953 年を対象とした産業連関表が作成され， それ以降各都道府県においてもその作成が進ん だ。図 1 は，5年間隔でその作成対象年次を示 したものであるが，1955 年を対象とした都道 府県が 7 都道府県（愛知県は 1953 年)，1960 年を対象とした都道府県が 18 都道府県である。 1960 年を対象とした産業連関表が全都道府県 の半数以上において作成されたが，その後順次 各都道府県で作成が進み，1990 年を対象とし た産業連関表から全ての都道府県で産業連関表 が作成された。

\section{(2) 地域間表の作成}

今回実施した調査によれば，地域間表をこれ まで作成した都道府県は 8 都道府県，北海道， 東京，神奈川，三重，大阪，兵庫，島根，福岡 である。先述したように例えば北海道では, 1985 年表から北海道を 4 つの地域に区分した 地域間産業連関表を作成している。1998 年表 からは道内を 6 地域に分割した表になり，現在 は 2005 年を対象とする地域間産業連関表が入 手可能である。

また，坪内（1991）によれば，愛媛県では県 
図 2 地域間表の作成状況

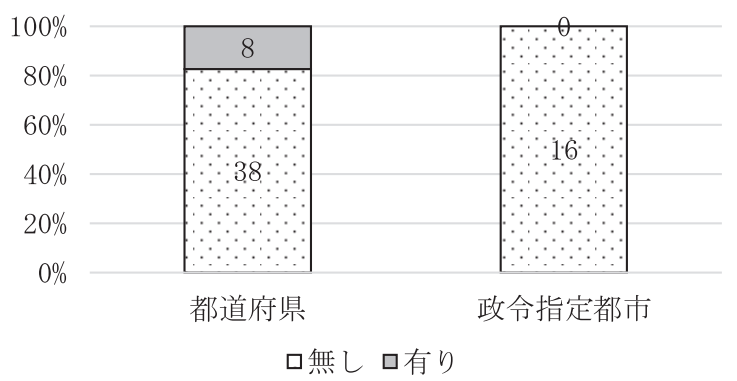

内を 6 地域に分割した各地域内表と地域間表を 作成しており, 過去に 1978 年表, 1983 年表, 1988 年表が作成されている。この表では，農 水産物流通状況調査, 鉱産物流通実態調査, 製 造業物資流通調査, 食肉・食鳥等流通実態調 査, 建設資材生産地調査, サービス業需要 (営 業）地域調査などが行われている。この時期に 愛媛県ではなぜ県内を分割した地域間産業連関 表が作成されたのであろうか。 その点について 坪内は, 愛媛県が歴史的, 地理的, 経済的に分 割するに適していたこと，また地域政策面での 時代背景があったことを説明している. 1977 年に国が国土の均衡ある発展「第三次全国総合 開発計画」を策定し，その開発コンセプトとし て「定住圈構想」を提唱している。定住圈構想 は, 地方を振興し, 過密過疎問題に対処しなが ら，全国土の利用の均衡を図りつつ，人間居住 の総合的環境の形成を図るというものである。 愛媛県ではこれを受けて 1978 年に第三次長期 総合計画を策定し，その中で愛媛県を 6 つのブ ロックに分けた「地方生活経済圈計画」が策定 された。この計画に沿って諸施策を企画・立案 するためには各圈域の経済実態とその関連構造
を把握する必要があるとして地域間産業連関表 作成が注目されたと考察している。

当該都道府県を中心としてその外の地域との 連関構造を把握するための地域間産業連関表 は, 東京都, 神奈川県, 三重県, 大阪府, 兵庫 県, 福岡県で作成されている。この中で例えば 大阪府では, 1960 年表から 1970 年表まで大阪 府・その他地域の 2 地域間産業連関表が作成さ れ, 1990 年表からは大阪府, 他近畿地域, 近 畿外地域の 3 地域間産業連関表が作成されてい る(伊藤他 (1997))。3 地域間表を作成した理 由として, 伊藤らは, 大阪府が近畿経済圈の中 心地として近畿各地と経済的に深く結びついて おり，大阪府内で行われた事業によって近畿地 域にどの程度の経済波及効果があるのか，また 他の近畿で行われた事業によって大阪府内にど の程度の波及効果があるのかを明らかにするこ とができるためとしている，大阪府では関西国 際空港の建設のように府県の枠を超えて広域的 に取り組むべき課題が多く，そのような事業の 計画等において役立つと考えられた。

\section{（3）雇用表}

雇用表は，都道府県ではほとんどの自治体で

図 3 雇用表の作成状況

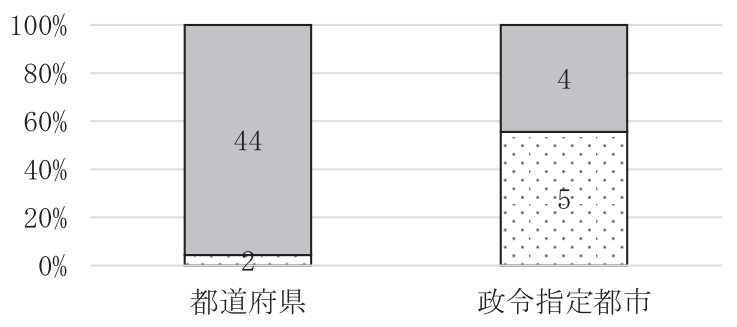

口無し口有り 
図 4 延長表の作成状況

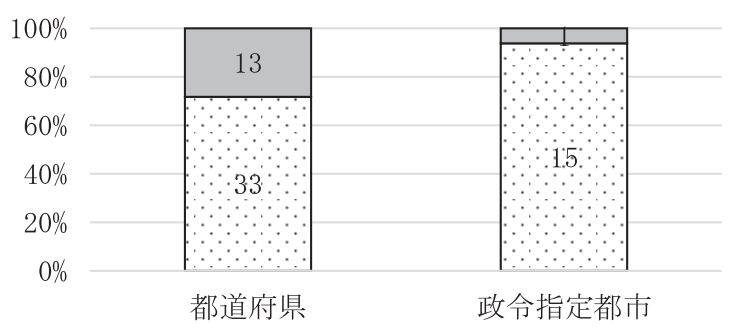

口無しロ有り

作成されている。公表部門数はほとんどの県で 100 部門程度の統合中分類となっているが，35 部門程度の都道府県も 4 県, 作成していない県 も 2 県ある。政令市は雇用表を作成していない 自治体が半数程あり, 都道府県と比較して作成 されていない状況である。公表部門数は都道府 県と同様 100 部門程度の政令市がほとんどであ る。

\section{（4） 延長表}

延長表を作成している都道府県は 13 あり， その多くは 2008 年，2009 年を対象年次として いる。産業連関表は 5 年に 1 回の間隔で作成さ れ，対象年次から公表年次までに 5 年程度の夕 イムラグが生じる。これを解消してできるだけ 近い年次の産業連関表を作成しようとしている 状況が分かる。一方政令市で作成しているのは 1市のみであった。

\section{3-3 作成体制}

産業連関表を作成する業務の担当者人数は,
都道府県では管理・実務担当の合計で 2 人とい う自治体が最も多く 16 団体，次いで 3 人が 12 団体であった１人という自治体も 9 団体あ り，ごく限られた人員で産業連関表が作成され ている，実務担当者の人数は 1 人という自治体 が最も多く，他の業務との兼任で作表が行われ ている.

政令市は管理・実務担当の合計で 2 人という 自治体が多かったが，実務担当者総数は 1 人と 2 人が最も多い. しかしそのほとんどが兼任と なっており，実務の専任担当者がいないと回答 した自治体は 11 団体あった。政令市は専任担 当者がいる自治体が都道府県より少ないが，図 5 にあるように外部委託により作成している自 治体も多く，全ての作業を外部委託していると いう政令市も回答のあった 12 団体のうち 4 団 体に上った。

表 1 業務担当人数別都道府県数

\begin{tabular}{|l|r|r|r|r|r|r|r|r|}
\hline & 0 人 & 1 人 & 2 人 & 3 人 & 4 人 & 5 人 & 6 人 & 計 \\
\hline 管理 ·実務合計 & 0 & 9 & 16 & 12 & 5 & 3 & 1 & 46 \\
\hline 実務担当総数 & 0 & 22 & 15 & 5 & 3 & 1 & 0 & 46 \\
\hline 実務専任担当 & 18 & 23 & 3 & 2 & 0 & 0 & 0 & 46 \\
\hline
\end{tabular}

表 2 業務担当人数別政令市数

\begin{tabular}{|l|r|r|r|r|r|r|}
\hline & 0 人 & 1 人 & 2 人 & 3 人 & 4 人 & 計 \\
\hline 管理. 実務合計 & 0 & 2 & 5 & 2 & 3 & 12 \\
\hline 実務担当総数 & 0 & 5 & 5 & 2 & 0 & 12 \\
\hline 実務専任担当 & 11 & 1 & 0 & 0 & 0 & 12 \\
\hline
\end{tabular}


図 5 業務委託の状況

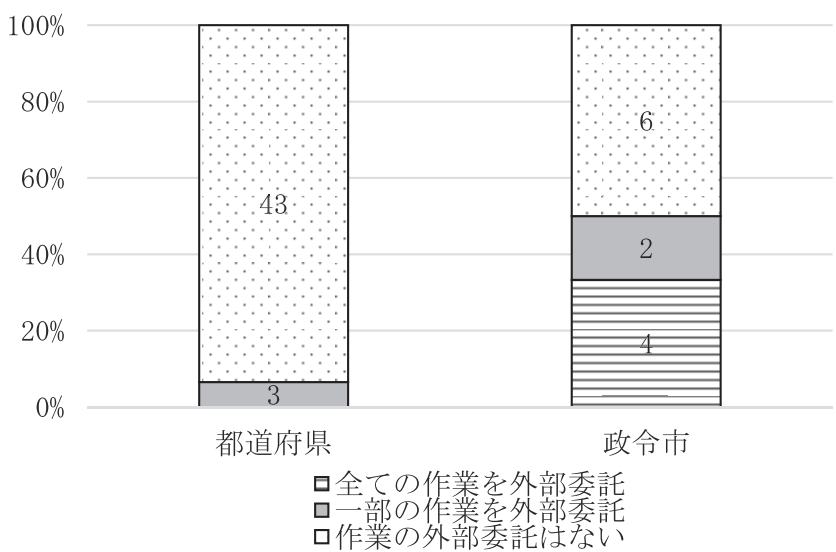

\section{3-4 部門の設定}

都道府県産業連関表の推計にあたっては全国 表の行部門 520 部門程度をべースに行っている が，公表部門の最大部門数は 190 部門程度の統
合小分類が 23 団体，100 部門程度の統合中分 類が 22 団体，残りの 2 団体はより細かい部門 設定になっている3)。そのため各都道府県の産 業構造を詳細に比較したい場合は 100 部門程度 で見ることが限界であろう。

図 6 仮設部門の設定

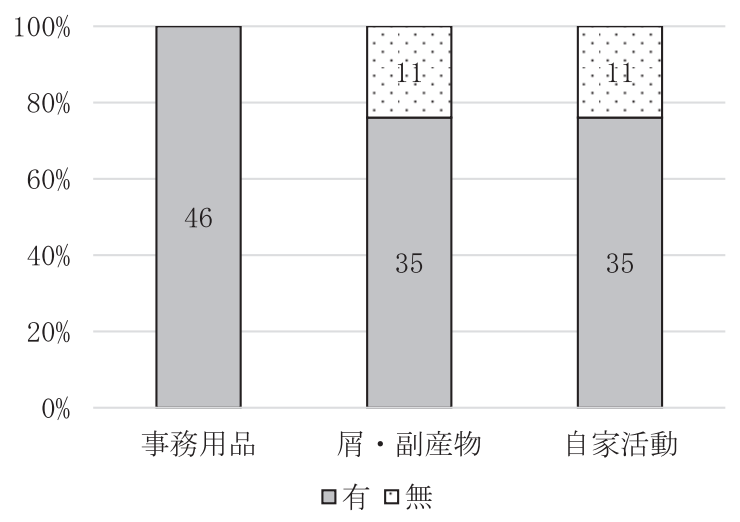

図 7 新設部門の設定

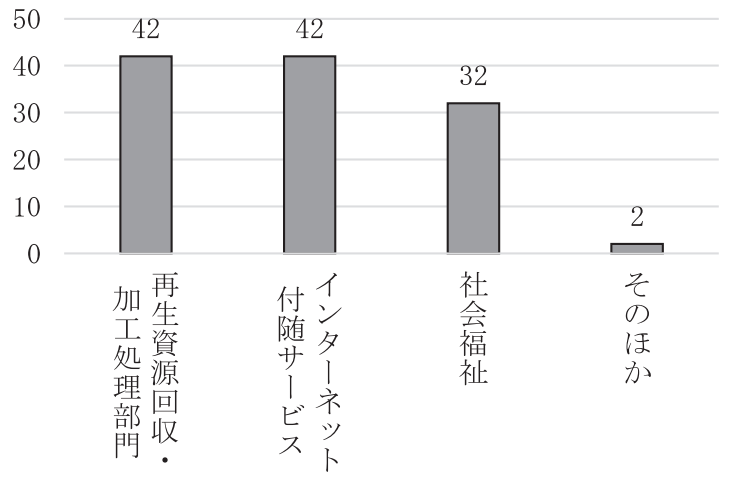


産業連関表の各内生部門には独立した一つの 部門として考えられないものがあり, それを 「仮設部門」と呼ぶ。仮設部門の代表的なもの に「事務用品」「屑・副産物」「自家活動」があ るが，事務用品は回答のあった 46 都道府県の 全てで設定され,「屑・副産物」「自家活動」に ついてはこれらの部門を設定していない都道府 県が 11 団体あった。自家部門は，ほとんどの 自治体で「自家輸送」を設定しているが，中に は「自家発電」を設定している団体もある。

比較的新しい分野として設定される部門に 「再生資源回収・加工処理部門」「インターネッ 卜付随サービス」「社会福祉」などがあるが, 「再生資源回収・加工処理部門」「インターネッ 卜付随サービス」については 42 都道府県,「社 会福祉」については 32 都道府県が部門設定し ている.

\section{3-5 特別調査の実施}

産業連関表を作成する手法には, サーベイ手 法とノンサーベイ手法，またサーベイ手法とノ ンサーベイ手法の併用としてのハイブリッド手 法（セミ・サーベイ手法）の 3 種類がある。都 道府県や政令市で作成されている地域産業連関 表は，主に既存の統計デー夕や全国産業連関表 などを用いて作成されるが, 地域独自の調査を 実施し, より精度の高い産業連関表を作成して いる地域がある。地域独自の調査にはいくつか あるが，地域産業連関表の作成において決定的 に重要なことに投入構造と地域内外の交易をど
のように捉えるかがある。

本稿の作成にあたって実施した調査による と, 投入調査を実施している都道府県は無かっ たが，政令市には投入調查を実施している市が あった。投入調査は全国の産業連関表を作成す る際に実施されており, 全国産業連関表は既存 の統計資料と投入調査から作成されており，地 域産業連関表の作成においてはこれらの結果を 間接的に利用することになる。つまり，各地域 における生産額に全国産業連関表の投入係数を 乗じることにより暫定投入表を推計する。同一 国であればアクティビティベースによる投入構 造は同じであり地域差は無いと仮定することに なる。しかし, 実際には地域特有の投入構造, 技術構造を持つことが考えられるため投入額の 推計は注意が必要である。例えば, 自動車は, 全国産業連関表の基本分類でも「乗用車」と 「トラック・バス・そのほかの自動車」の 2 種 類に分類されているが，昨今では自動車にも八 イブリッド車や電気自動車なども普及しつつあ り，その投入構造は異なることが知られてい る . 地域的には次世代自動車の生産拠点があ る場合もあり，地域固有の投入構造を知るため の特別調査を必要とする場合もあるだろう。

地域間交易の把握は, 地域産業連関表の作成 においては決定的に重要な要素である。特に最 終需要による生産誘発効果を推計する際に用い られる均衡産出高モデルにおいては, 自給率を 計算する部分がある。この自給率の大きさによ って生産誘発効果の額はかなり変動する。自給

図 8 投入調査の実施

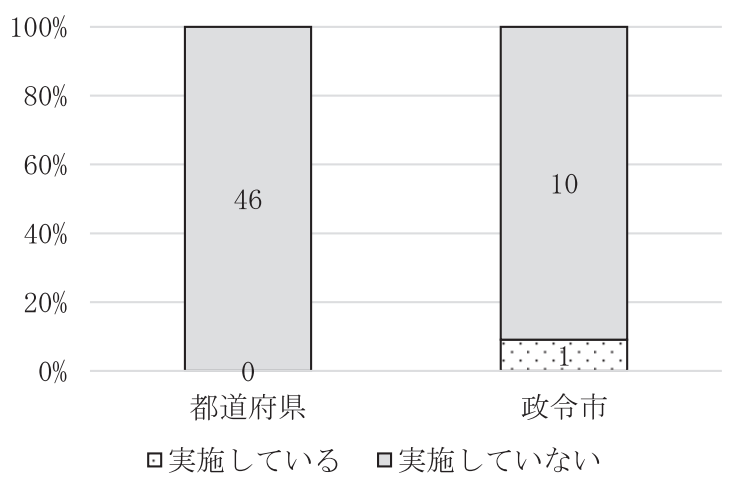


図 9 移出入調查の実施

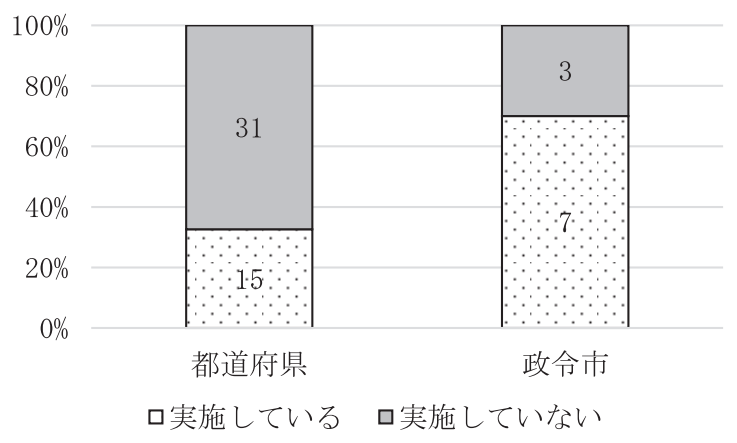

表 3 移出・移入調查の別

\begin{tabular}{|l|r|r|r|r|}
\hline & 移入のみ & 移出のみ & 両方 & 合計 \\
\hline 都道府県 & 0 & 9 & 5 & 14 \\
\hline 政令市 & 0 & 2 & 5 & 7 \\
\hline
\end{tabular}

図 10 輸出入調查の実施

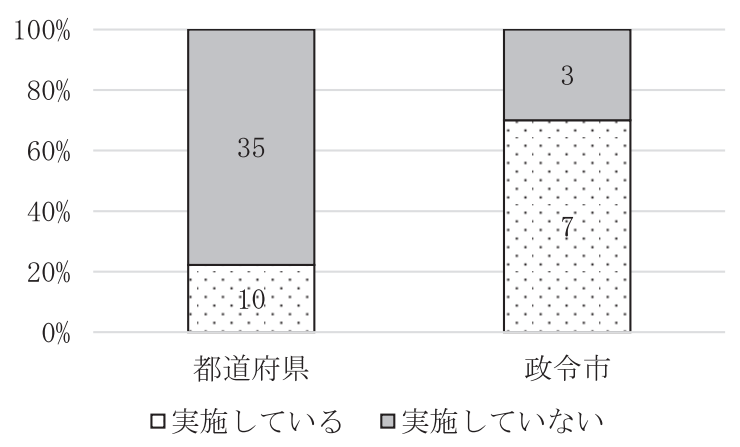

率は移輸入係数によって決まるため, 産業連関 表において移輸入を精度よく推計する必要があ る。地域間交易を推計するためには，都道府県 では経済産業省による商品流通調査の結果を利 用することが一般的である。ささらに詳細な実態 や推計誤差を少なくするために, 都道府県独自 で商品流通調查等の交易関連調査を実施する場 合がある。この実態を調査したところ，都道府 県では回答のあった 46 団体のうち 15 団体, 政 令市では 10 団体のうち 7 団体が独自の調查を 行っているということであった。 また，この独 自調查には経済産業省の商品流通調查を補完す る目的で行われるものと, 同調査では把握しき れない部門の交易実態を把握するものがある が，特にサービス業についてはその対象外とな っているため, 都道府県独自に調査を行ってい
る場合がある。例えば神奈川県では「サービス 業県外売上額調査」と「研究機関に関する調 査」を実施し，第三次産業の交易実態の把握に 努めている。また, 政令市である川崎市は, 神 奈川県に拈りる「神奈川県製造業物資流通調 査」,「サービス業県外売上調査」,「研究機関に 関する調查」を利用する他，市独自の調查とし て「製造業に関する調查」，「直接購入に関する 調查 (WEB アンケート調查) 」,「かわさき市 民アンケート調查の結果」を利用して移出入や 市内生産額を推計している。戸松（2013）で は，神奈川県の産業連関表作成のための特別調 査と県内政令市との協力体制について解説され ており, 今後の地域における産業連関表作成の ための特別調査のあり方を検討するにあたり参 考となるであろう。 
図 11 移輸入の分離

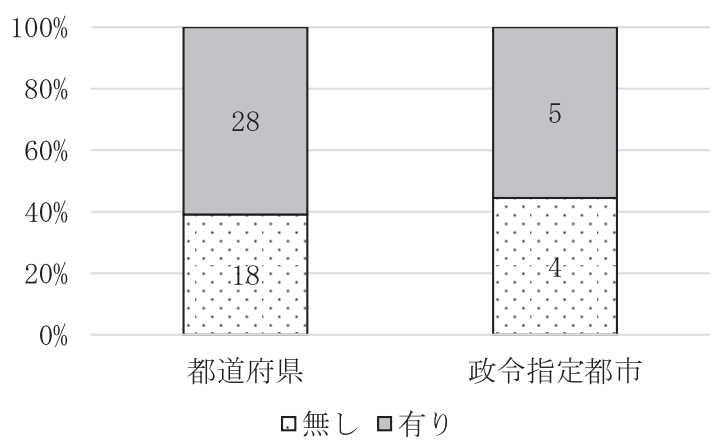

図 12 移輸出の分離

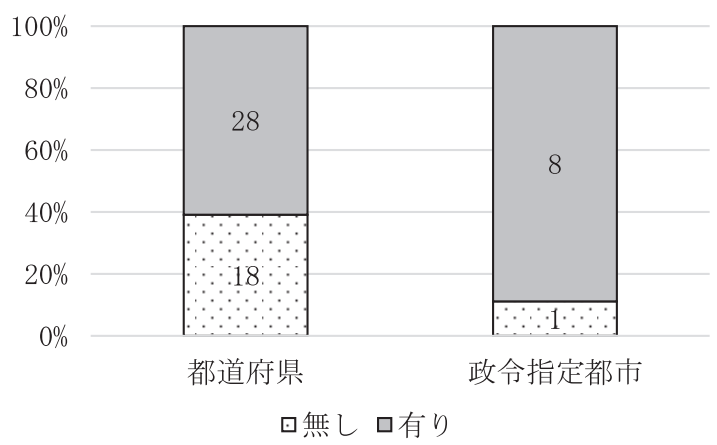

地域間交易は当該地域にとっては移出，移入 の両方があるが，移出のみを調査している自治 体が都道府県では回答のあった 14 団体中 9 団 体，政令市では 7 団体中 2 団体であった。移出 と移入の両方を調査している団体は, 都道府 県，政令市共に 5 団体であり，割合では政令市 の方が移入実態を独自調査により把握しょうと している。なお，移入のみを調査している自治 体は無かった。また，輸出入については独自調 査を行っている都道府県は移出入調査を行って いる自治体に比べて少ないという結果だった。

移入と輸入，移出と輸出はそれぞれ分離され ていた方が，国内交易が多いのかそれとも海外 貿易が多いのかなどの構造が分析でき，また当 該地域とその地域外の全国（その他全国）との 2 地域間モデルを構築できる（片田他 (1994))。このモデルを用いることによって当 該地域の需要増が当該地域とその他全国に及ぼ す波及効果を分析することができる。調査の結 果では, 移輸入が分離されているのは 46 団体
中 28 団体，政令市では 9 団体中 5 団体であり, 移輸出が分離されているのは，都道府県では同 じく 28 団体，政令市では 8 団体であった。

\section{3-6 2011 年表の公表と今後の作成}

都道府県の産業連関表は 1990 年から全ての 都道府県で揃うようになったが，これまで末尾 が 0 と 5 の年を対象年次として作成されてき た。しかし，全国産業連関表が 2011 年を対象 年次とした産業連関表となり，都道府県もそれ に呼応して 2011 年産業連関表を作成している。 この公表時期を調査したところ，2015 年 9 月 現在の回答として 2016 年 3 月までに公表する と回答した団体が 34 団体，同年 9 月までと回 答した団体が 4 団体，2017 年 3 月までが 4 団 体であった。未定と回答した都道府県も 4 団体 あったが，2017 年 3 月までには全ての都道府 県で利用可能になると思われる.

政令市については，回答のあった 12 団体の うち 7 団体が 2016 年 10 月から 2017 年 3 月と 

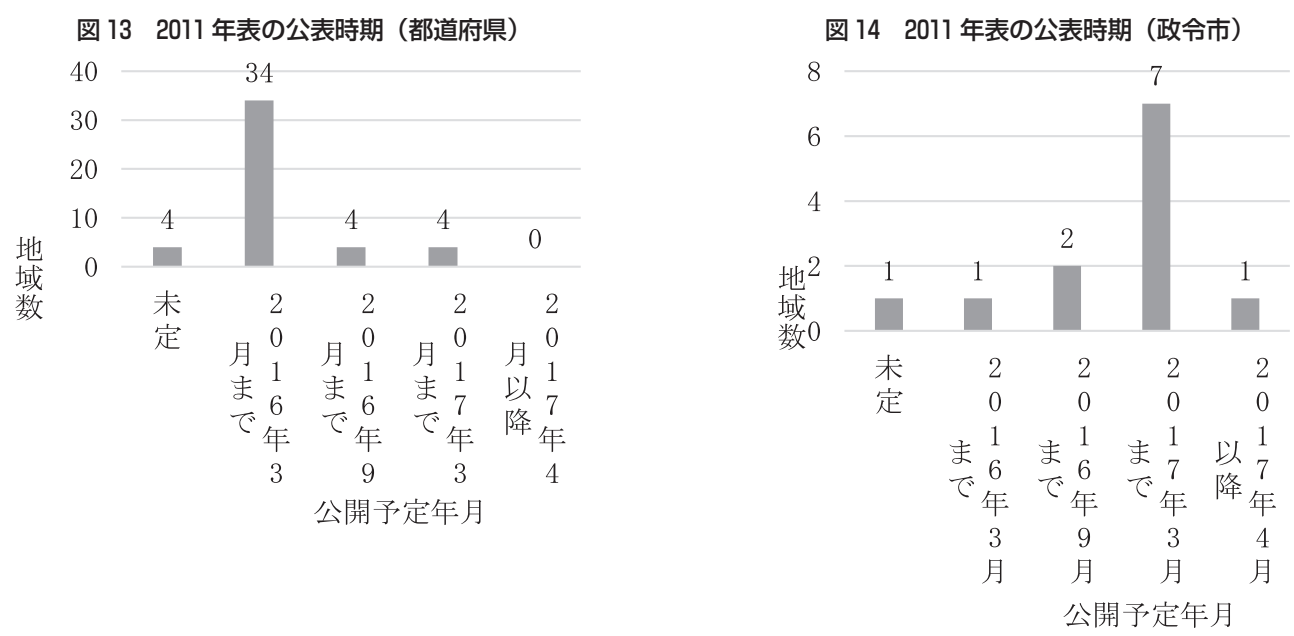

図 15 今後の地域産業連関表の作成

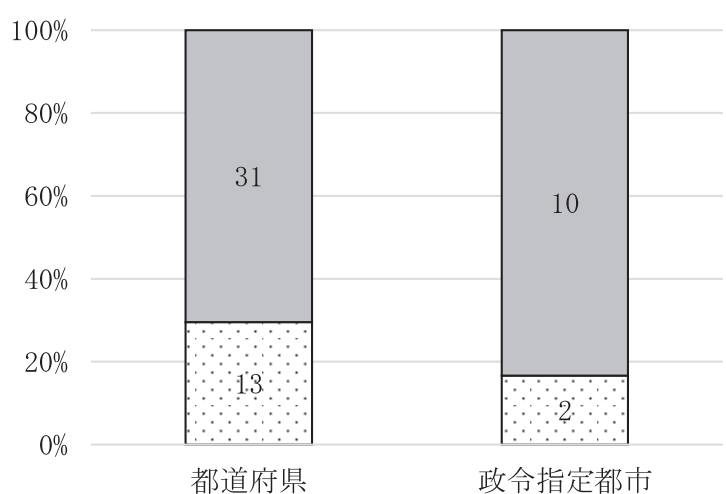

口今後も産業連関表は継続的して作成

口今後作成・公表が困難になる

図 16 今後の作表が困難な理由

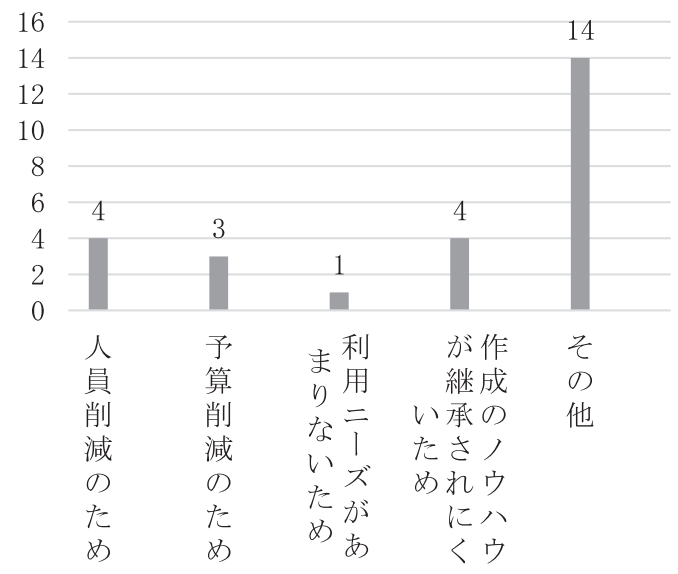


回答しており, 都道府県と比べて公表は遅くな る傾向にある。

最後に, 今後の地域産業連関表の作成が困難 になるかに関して尋ねたところ, 都道府県では 44 団体中 13 団体, 政令市では 12 団体中 2 団 体が「今後作成, 公表が困難になる」と回答し た。その理由としては，「人員削減のため」, 「作成のノウハウが継承されにくいため」とい った理由が多かったが，その他の理由として，

「廃止される統計調査の増加により推計が困難 になる」などの回答が見られた。また最も多か った理由は,「経済産業省の商品流通調査が実 施されないことから都道府県の移出入の推計が 困難になる」という回答であった。先に示した ように地域産業連関分析においては，地域間交 易の推計精度が重要であり, この精度が落ちた り推計自体が困難になることは今後の地域産業 連関表を用いた分析において極めて憂慮すべき 問題である。

経済産業省で実施されてきた商品流通調査は 1965 年に開始され，これまで地域間における 商品流通状況を明らかにし, 地域産業連関表及 び関係都道府県が作成する地域産業連関表のた めに大いに用いられてきた。平成 23 調査では 26,129 事業所を対象とし回収率は $58.2 \%$ であ った5)，仮に国が商品流通調査を行なわず，各 都道府県が独自に調查を実施することになれ ば，その費用は単一団体（国）が実施するより 総計としては多額な費用と労力が必要となり極
めて効率が悪いばかりでなく, 全国を対象とし た調査でなければ，地域間交易の推計精度が大 きく落ちることが予想される，また，国が実施 することで事業所からの回収率は高いと考えら れる。地方に扔ける人口減少や地域経済の衰退 が懸念される中においては着実に政策分析を行 う必要があり，そのためにもこのような地域経 済統計の根幹を成す調查が実施される必要があ ろう。

\section{3-7 分析ツール}

地域産業連関表を活用するためには，基本的 な考え方を理解したうえで，できるだけ容易に 分析ができることが必要である。各自治体では その利用を広めるため様々な努力がなされてお り，分析ツールの提供もその例である。分析ツ ールがある自治体は都道府県では 46 都道府県 中 42 団体, 政令市では 7 団体であり多くの自 治体において分析ッールがある。分析ッールの 公表は都道府県では回答のあった 44 都道府県 のうち 31 団体であり, 政令市では 7 団体のう ち 1 団体である. 現在は表計算ツールが普及し ており，そのアプリケーション自体の使用方法 が分かれば基本的な分析は可能であるが，まだ 分析に慣れていない人や団体にとっては自治体 が提供している分析ツールを活用することでそ の利用は増えるであろう。また, 様々な利用例 を示すことで，産業連関分析あるいは政策分析 に関心のある者にとって利用範囲が増えると考

\section{図 17 分析ツールの有無}

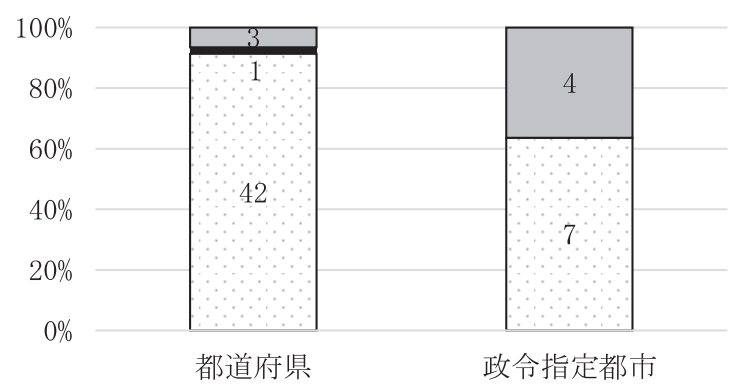

ロ分析ツールはない (Excel等のソフトで計算)

口他機関が開発した分析ツールを所有

ロ独自開発した分析ツールを所有 
図 18 分析ツールの公表

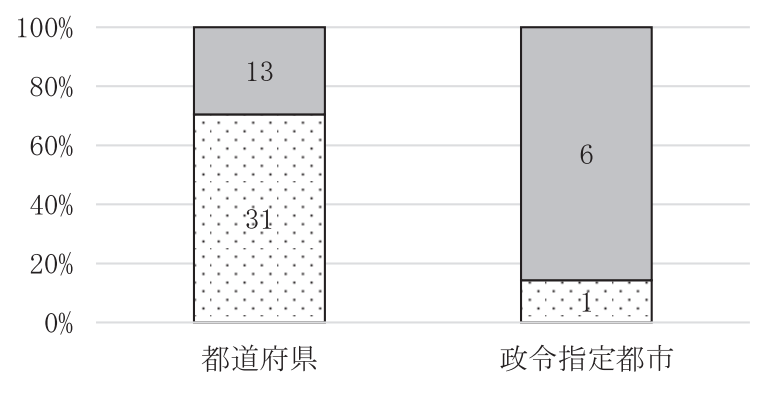

ロ公表している ロ公表していない(組織内利用)

えられる。例えば兵庫県では, 様々な部門にお ける経済波及効果の分析例だけでなく，イベン 卜，企業立地，建設投資，高齢者福祉施設立 地, 輸出増加などによる経済波及効果分析や, 生産活動が大気環境等の環境に与える分析, 価 格分析を例としたエクセルワークシートを提供 しており，産業連関表の様々な利用例とその範 囲を知ることができる。

\section{4. 都道府県産業連関表で用いら れる分析手法}

今回実施した調査では，最終需要増による経 済波及効果を分析する際, 直接的な需要増とそ れによる生産増が更に消費を増加させる効果を どのように計算しているかという設問を設け た。その結果は全ての都道府県と政令市で, 「直接効果とそれによる生産波及効果（一次波 及効果), これらの生産により雇用者所得が増 加し，それによる消費増がさらに生産を誘発す る効果 (二次波及効果) を別々に算出し，それ らの合計として消費を考慮した分析を行ってい る」という回答であった。これは従来から都道 府県や各調查機関が実施している一般的な方法 であるが，この需要増による生産増がさらに所 得増を引き起こしそれが新たな消費需要となっ て生産を引き起すという効果は, 消費内生化モ デル（例えば石川（1998））による算出が世界 的には一般的である。

\section{5. まとめ}

日本の地域産業連関表が作成され始めてから 既に 60 年近くの歴史がある。比較的大きな地 域ブロックの産業連関表から市町村レベルの産 業連関表まで様々な地域産業連関表が数多く作 成されているこの状況は, 今後の地域産業連関 分析関連の研究の発展や実際の地域政策分析へ の適用など大いに期待できるものである。しか し, 今回実施した都道府県及び政令指定都市へ のアンケート調査を通じて, 以下のような課題 が浮かび上がった。

(1)都道府県の産業連関表は 1990 年表から全国 で利用可能になり，またそれを用いた全国 47 都道府県間産業連関表の作成されるよう になったが，県を分割した県内地域間産業連 関表の作成はまだごく限られた自治体におい てである。これには特に地域間交易の推定に おいてまだその方法が定着していないことが 理由として考えられる。近年では地域間交易 推計のノンサーベイ手法, サーベイ手法の議 論も活発に行われているため，これらの知見 を実務にも活用する余地があるだろう。ま た，延長表の作成も限定的である。産業連関 表は 5 年に一回のペースで作成され, その公 表時期もタイムラグが長いことから延長表を 作成する方法論の議論も踏まえ実務に活かす 必要があるだろう。

(2)多くの都道府県や政令市では少ない職員で作 成作業を行っている。また，人事異動のため 
にノウハウが定着しないなどの問題もある。 国や学会等が安定的に研修を行い, 常に地方 自治体でも産業連関表に関する知識と作成の ノウハウを保持していく必要がある。

(3)都道府県や政令市で投入調査を行っている自 治体はほとんど無かった。しかし, 先端産業 など地域によっては全国的には少ない製品の 生産に特化している地域もあるため, 独自の 投入調查の方法の検討や, 新技術の投入構造 の調査研究の蓄積も重要である。

(4)地域産業連関表の作成において最も重要な要 素は，地域間交易の把握である。これまで都 道府県などでは経済産業省による商品流通調 查を活用してきたが，このような交易状況を 把握する全国レベルの調查は極めて重要であ る。個別の地域でこのような調査を行うのは 効率が極めて悪く, これまでのような精度も 期待できない。また, 経済産業省の地域間産 業連関表は，これまで多方面で利用されてお り, 例えば東日本大震災後の経済分析でも, 数多く利用された（例えば，下田・藤川 （2012）など）。宮城・石川（2003）による全 国都道府県産業連関表の作成においてもその 一部において経産省の地域間産業連関表を用 いている。この地域間産業連関表は, 日本の 地域産業連関表の根幹を成すと考えていいだ ろう.

\section{参考文献}

旭川市（2006）「平成 12 年旭川市産業連関表」

朝日幸代 (2004) 「平成 7 年名古屋市産業連関表の作成 の試み」『産業連関』, 第 12 巻 1 号, pp. $16-$ pp. 24 , 2004.

芦谷恒憲・後藤啓 (2015)「兵庫県内 7 地域産業連関表 の推計による地域経済圈の経済効果分析」『産業連 関』，第 22 巻 3 号, pp.106-114.

石川良文（1998）「中部国際空港および関連プロジェク 卜の経済波及効果」『産業連関』, 第 8 巻第 2 号 pp. 64-70.

石川良文・小池淳司 ·上田孝行 (2001)「Non-Survey 手法による都市圈産業連関表の作成」『土木学会第 56 回年次学術講演会講演概要集』CD-ROM.

石川良文・宮城俊彦（2004）「全国都道府県間産業連関 表による地域間産業連関構造の分析」『地域学研究』,
第 34 巻 1 号, pp. 139-152.

石川良文 (2008)「統計情報を活用したアジア国際日本 地域間産業連関表の作成手法」『南山経済研究』, 第 22 巻第 3 号, pp.93-107.

石川良文（2013）「地域間産業連関表を用いた公共投資 の地域経済効果分析」『都市問題』, 第 104 巻第 6 号, pp57-62.

市村真一 ・王慧昫（2004）『中国経済の地域間産業連関 分析』, 創文社.

伊藤正一 - 橋一亮 - 平良信夫 - 南野由美 (1997)「大阪 府地域間産業連関表の概要」『産業連関』, 第 7 巻第 2 号, pp.46-53.

今井泉（2015）「美作市における小地域産業連関表の作 成過程と課題」『産業連関』, 第 22 巻第 $1 \cdot 2$ 号, pp. 21-34.

今西英俊 (2004)「深川市産業連関表の作成手法の研 究」『産業連関』, 第 12 巻 3 号, pp.38-49.

岡本信広（2013）「中国の地域（省市自治区）産業連関 モデルと移輸入」『中央大学経済研究所年報』, 第 44 号, pp.201-222.

片田敏孝・森杉壽芳・宮城俊彦・石川良文（1994）「地 域内産業連関分析におけるはね返り需要の計測方法」 『土木学会論文集』, No.488 / V - 23, pp.87-92.

亀畑義彦・小野寺英明 (1991), 「産業連関表による旭 川市分析の試み」, 『イノベーション＆ I-O テクニー ク』, 第 2 巻第 2 号, pp. 58-65.

関西社会経済研究所 (2008)『関西地域間産業連関表の 作成方法 2000 年版』.

釧路市（2015）『平成 17 年釧路市産業連関表』,

小副川忠明 - 居城环 - 金丹 - 長谷部勇一 (2006)「平成 12 年横浜市産業連関表と大学の地域経済効果」『産業 連関』, 第 14 巻 1 号, pp.56-67.

下田充・藤川清史 (2012)「産業連関分析モデルと東日 本大震災による供給制約」『産業連関』, 第 20 巻第 2 号, pp.133-146.

高畑由洋（1992）「北海道の地域間産業連関表」『イノ ベーション\& I-O テクニーク』, 第 3 巻第 3 号, pp. 24-29.

中部産業・地域活性化センター（2011）『中部圈地域間 産業連関表 (2005 年版)』

坪内建広 (1991)「愛媛県の地域間産業連関表につい て」『イノベーション \& I-O テクニーク』第 2 巻第 1 号, pp.35-42.

電力中央研究所（2008）『47都道府県多地域産業連関表 の開発一内部 - 外部乗数による都道府県間生産誘発 構造の分析一』

東北活性化研究センター（2011）『平成 17 年東北地域 県間産業連関表に関する報告書』,

戸松宏（2013）「神奈川県産業連関表の作成について」

『産業連関』, 第 21 巻 $1 \cdot 2$ 号, pp.3-13. 
中澤淳治（2002）「市町村地域産業連関表の作成とその 問題点」『政策科学』, 第 9 巻第 2 号, pp.113-pp. 125.

長谷川良二・安高優司 (2009)「福知山市接続産業連関 表の作成の試み」『産業連関』, 第 17 巻 3 号, pp.7586.

日吉拓也 ·河上哲 · 土井正幸 (2004)「ノンサーベイ · アプローチによるつくば市産業連関表の作成と応用」 『産業連関』, 第 12 巻 1 号, pp.3-15.

吹谷忠施（1994）「北陸地域産業連関表について」『イ ノベーション\& I-O テクニーク』, 第 5 巻 3 号, pp. 74-83.

本田豊 · 中澤純治（2000）「市町村地域産業連関表の作 成と応用」『立命館経済学』, 第 49 巻第 4 号, pp. 409-434.

丸山貞夫 (1992)「昭和 60 年東京圈産業連関表につい て」『イノベーション\& I-O テクニーク』, 第 3 巻 1 号, pp.49-55.

宮城俊彦 - 石川良文 - 由利昌平 - 土谷和之 (2003)「地 域内産業連関表を用いた都道府県間産業連関表の作 成」『土木計画学研究·論文集』, vol.20 Nol, pp. 87-95.

山田光男（1995）「三重県内地域間産業連関表」『イノ ベーション\& I-O テクニーク』, 第 5 巻第 4 号, pp. $52-67$.

渡部英俊（2008）「地域産業連関表推計方法等に関する 情報収集」『産業連関』, 第 16 巻 1 号, pp.17-25.

Chenery, H. B. (1956). Interregional and International Input-Output Analysis. In: T. Barna (ed.), The Structure Interdependence of the Economy, New York: Wiley, pp. 341-356.

Institute of Developing Economics, Japan External Trade Organization (2007), Transnational Interregional Input-Output Table between China and Japan.

Hirsch, W. Z (1959), "Interindustry Relations of a Metropolitan Area”, The Review of Economics and Statistics, No.4, pp.360-369.

Institute of Developing Economies Japan External Trade Organization Japan (2003), Multi-Regional Input-Output Model for China 2000.

Isard, W (1951), "Interregional Input-Output Analysis: a Model of a Space Economy", Review of Economics and Statistics, Vol.33. No.4, pp318-328.

Leontief, W (1936), “Quantitative Input-Output Relations in the Economic System of the United States", Review of Economics and Statistics, Vol.18, No.3, pp105-125.

Moses, L. M (1955), “The Stability of Interregional Trading Patterns and Input-Output Analysis”, The American Economic Review, Vol.45, No.5, pp.803826.

Moore, F. J. \& J. W. Petersen (1955), "Regional Analysis : An Inter-industry Model of Utah”, Review of Economics and Statistics, Vol.37, No.4, pp.368-383.

Willian B. Beyers and Ta-Win Lin (2015), The 2007 Washington Input-Output Study.

\section{[注]}

1） 2000 年の地域間産業連関表は公式な作成が中止 となったため, 新井園枝・尾形正之により試算地 域間産業連関表として個人により作成された。

2）本調査は，2015 年 9 月に郵送法により実施し た. 但し，E-Mailによる回答を認めたため，一部 の自治体からはメールにより回収した。回収率は 都道府県 $97.9 \%$ ，政令市 $85 \%$ であった。

3）ここでは，175 から 199 部門を 190 部門程度, 97 部門から 110 部門を 100 部門程度と呼んでい る.

4) 例えば, 中部圈社会経済研究所 (2015) では, 次世代自動車の投入係数が異なることが示されて いる。

5）経済産業省商品流通調査の概要 http://www. meti. go.jp/statistics/tyo/ryuutuu/gaiyo. html\#me nu04（2015 年 10 月 1 日閲覧）

本稿の作成にあたっては, 2015 年度南山大学パッ へ研究奨励金 I-A-2（特定研究助成 - 一般）の助成 を受けた。

また，アンケート調査の実施にあたって，数多く の自治体から回答があった。ここに感謝の意を表す。 なお，各都道府県・政令指定都市に行ったアンケー 卜調査の入力 · 集計作業において南山大学大学院加 藤秀弥君の協力を得た. 